\title{
Scope note
}

Genome Research publishes studies on the structure, function, biology, and evolution of genomes of all organisms, with a long-standing emphasis on genome-scale analyses, chromatin structure and function, epigenomics, systems genetics, and proteomics. We also feature gene discoveries that provide novel insights and reports of high-throughput experimental and computational approaches. In addition to these core areas, the journal is now particularly interested in the following areas:

1. comprehensive characterization of genome sequence variation

2. understanding the basis of phenotypic complexity

3. network biology and the functional effects of genetic variation

4. evolutionary mechanisms of species origin, adaptation, and genomic diversity, including the study of ancient DNA

5. genomic medicine, including mechanisms of penetrance, expressivity, and modifier effects

6. understanding genomic and biological processes through single-cell analyses

7. novel computational algorithms that provide insight into biological processes

8. genome editing and engineering

Genome Research is cross-disciplinary, publishing studies that reflect aspects of the above areas in disease and medicine, neuroscience, microbiology, and human, animal, and plant biology.

The Editors of Genome Research 


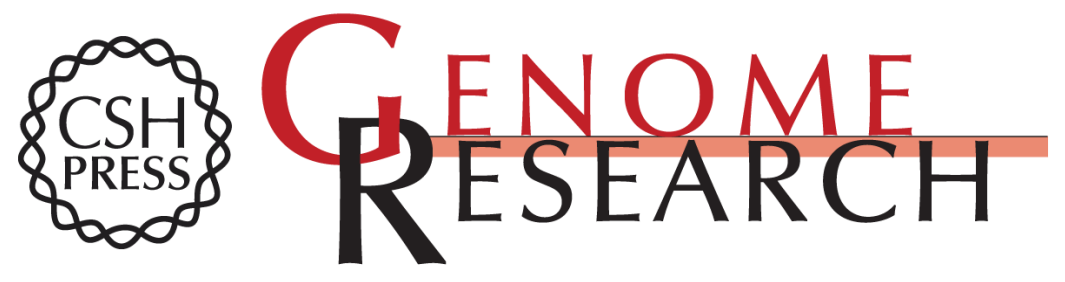

\section{Scope note}

Genome Res. 2018 28: x originally published online April 12, 2018

Access the most recent version at doi:10.1101/gr.236893.118

Open Access Freely available online through the Genome Research Open Access option.

Creative This article, published in Genome Research, is available under a Creative

Commons Commons License (Attribution-NonCommercial 4.0 International), as described at License http://creativecommons.org/licenses/by-nc/4.0/.

Email Alerting Receive free email alerts when new articles cite this article - sign up in the box at the Service top right corner of the article or click here.

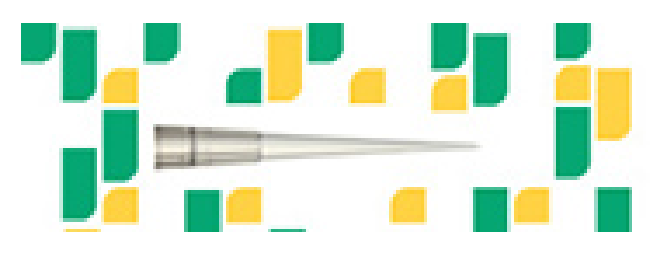

To subscribe to Genome Research go to: https://genome.cshlp.org/subscriptions 